\title{
Effect of Clay Mineralogy on Iron Bioavailability and Rhizosphere Transcription of 2,4-Diacetylphloroglucinol Biosynthetic Genes in Biocontrol Pseudomonas protegens
}

\author{
Juliana Almario, Claire Prigent-Combaret, Daniel Muller, and Yvan Moënne-Loccoz \\ Université de Lyon, F-69622, Lyon, France; Université Lyon 1, Villeurbanne, France; and CNRS, UMR5557, Ecologie \\ Microbienne, Villeurbanne, France
}

Submitted 25 November 2012. Accepted 5 February 2013.

\begin{abstract}
Pseudomonas strains producing 2,4-diacetylphloroglucinol (DAPG) can protect plants from soilborne phytopathogens and are considered the primary reason for suppressiveness of morainic Swiss soils to Thielaviopsis basicola-mediated black root-rot disease of tobacco, even though they also occur nearby in conducive sandstone soils. The underlying molecular mechanisms accounting for this discrepancy are not understood. In this study, we assessed the hypothesis that the presence of iron-rich vermiculite clay (dominant in suppressive soils) instead of illite (dominant in neighboring conducive soils) translates into higher levels of iron bioavailability and transcription of Pseudomonas DAPG synthetic genes in the tobacco rhizosphere. Rhizosphere monitoring of reporter gene systems pvd-inaZ and phlA-gfp in Pseudomonas protegens indicated that the level of iron bioavailability and the number of cells expressing phl genes (DAPG synthesis), respectively, were higher in vermiculitic than in illitic artificial soils. This was in accordance with the effect of iron on phlA-gfp expression in vitro and, indeed, iron addition to the illitic soil increased the number of cells expressing $p h l A-g f p$. Similar findings were made in the presence of the pathogen $T$. basicola. Altogether, results substantiate the hypothesis that iron-releasing minerals may confer disease suppressiveness by modulating iron bioavailability in the rhizosphere and expression of biocontrol-relevant genes in antagonistic $P$. protegens.
\end{abstract}

Many plant-growth-promoting rhizobacteria have positive effects on plant health, which may take place via different modes of action; noticeably, induced systemic resistance (ISR) and direct phytopathogen inhibition (Haas and Défago 2005; Raaijmakers et al. 2009). Antimicrobial secondary metabolites often play a key role in these plant-protection effects, especially the Pseudomonas compound 2,4-diacetylphloroglucinol (DAPG), which can both induce systemic resistance (Iavicoli et al. 2003; Weller et al. 2012) and inhibit various root patho-

Corresponding author: Y. Moënne-Loccoz; Telephone: +33-(0)4 724313 49; Fax: +33-(0)4 724312 23; E-mail: yvan.moenne-loccoz@univlyon1.fr

* The $e$-Xtra logo stands for "electronic extra" and indicates that two supplementary figures and two supplementary tables are published online.

(C) 2013 The American Phytopathological Society gens (Couillerot et al. 2009; Haas and Défago 2005). DAPG can also trigger gene expression of phytobeneficial functions in neighboring plant-protecting bacteria and fungi (Baehler et al. 2005; Combes-Meynet et al. 2011; Lutz et al. 2004).

Soilborne populations of DAPG-producing fluorescent Pseudomonas spp. are implicated in the natural suppressiveness of certain soils toward particular fungal phytopathogens (Kyselková and Moënne-Loccoz 2012), such as Gaemannomyces graminis var. tritici (take-all of wheat) (Weller 2007), Fusarium oxysporum f. sp. pisi (Fusarium wilt of pea) (Landa et al. 2002), and Thielaviopsis basicola (black root-rot of tobacco) (Frapolli et al. 2010). Soils specifically suppressive to black root rot of tobacco (and other crops) are mainly documented in the region of Morens (Switzerland). At Morens, disease suppressiveness is a microbial property of the soil (Stutz et al. 1986) involving DAPG-producing pseudomonads (Haas and Défago 2005), and inactivation of DAPG production ability in the Morens isolate Pseudomonas protegens CHA0 abolished its ability to suppress black root rot (Keel et al. 1992).

Morens soils are of particular interest from a molecular plant-microbe interaction standpoint because, in that region, conducive soils (formed from sandstone sediments) also occur in the vicinity of suppressive soils formed from glaciers' shallow morainic deposits overlying the sandstone (Stutz et al. 1985). Yet, both types of soil belong to the same brunisol category and are chemically similar, except for the predominance of iron-releasing vermiculite clay in suppressive soils versus illite clay in conducive soils (Stutz et al. 1989). This led to the hypothesis (Almario et al. 2013; Ramette et al. 2003) that iron released from vermiculite triggers transcription of Pseudomonas DAPG synthetic genes in suppressive soils to levels higher than those in conducive soils, where DAPG-producing Pseudomonas populations are also present at high levels (Almario et al. 2013; Frapolli et al. 2010) but where iron availability is supposedly lower (Keel et al. 1989; Voisard et al. 1989). Indeed, $P$. protegens $\mathrm{CHA} 0$ can retrieve iron from vermiculite (Müller 2009). Earlier work with artificial soils mimicking texture and clay mineralogy of Morens suppressive (vermiculitic) and conducive (illitic) soils did show that i) total and soluble iron contents (Keel et al. 1989) and ii) plant protection by P. protegens CHA0 (Keel et al. 1989) and other DAPG-producing pseudomonads (Ramette et al. 2006) were higher in vermiculite-rich than in illite-rich soils. However, whether or not iron bioavailability for pseudomonads and transcription of Pseudomonas DAPG synthetic genes in the rhizosphere were higher in the presence of vermiculite has not been assessed thus far. 
Under soil-less laboratory conditions, root expression of Pseudomonas DAPG synthetic genes (phlACBDE operon) is influenced by biotic factors such as plant species, plant cultivar, pathogen presence, and plant health (de Werra et al. 2008; Jamali et al. 2009; Jousset et al. 2011; Rochat et al. 2010). Abiotic factors such as Zn, Mo, and Fe concentrations can also modulate DAPG production in Pseudomonas spp. depending on culture medium conditions (Dowling et al. 1996; Duffy and Défago 1999). Recently, Lim and associates (2012) showed that iron had a strong impact on the transcriptome and proteome of the DAPG producer $P$. protegens $\mathrm{Pf}-5$ and, in particular, iron-induced expression of DAPG synthetic genes in vitro.

The objective of this study was to assess the hypothesis that iron bioavailability for pseudomonads and transcription of $\mathrm{Pseu}$ domonas DAPG synthetic genes in the tobacco rhizosphere are higher in the presence of vermiculite than illite, which are the dominant clay types in soils suppressive and conducive, respectively, to Thielaviopsis black root rot. To this end, the artificial vermiculitic and illitic soils of Keel and associates (1989) were used, along with a mechanistic approach based on expression analysis of reporter gene systems $p v d$-inaZ (iron availability) and phlA-gfp (transcription of DAPG synthetic genes) on rhizosphere-stable plasmids (Rochat et al. 2010), which was complemented by real-time reverse-transcriptase polymerase chain reaction (RT-PCR) analysis of phlA-gfp transcription in DAPG-producing $P$. protegens.

\section{RESULTS}

\section{Effect of bioavailable iron on cell density and} phlA-gfp expression of $P$. protegens in vitro.

Increasing the in vitro iron concentration up to $5 \mu \mathrm{M}$ with FeEDDHA, a chelated iron form bioavailable to Pseudomonas spp. (Keel et al. 1989), enhanced cell density (estimated by optical density at $600 \mathrm{~nm}\left[\mathrm{OD}_{600}\right]$ values at $38 \mathrm{~h}$ ) (Fig. 1A) of $P$. protegens CHA0(att Tn7::miniTn7-Gm- $\mathrm{P}_{\text {tac }}$-mcherry; pME7100), in which a plasmid-borne copy of the DAPG synthesis promoter phlA is fused to the promoterless reporter gene green fluorescent protein ( $g f p$ ) (Rochat et al. 2010). This strain is hereafter referred to as CHA0-mche(pME7100), as in Rochat and associates (2010). Additional increases of FeEDDHA concentration did not enhance cell density of the strain any further.

Bioavailable iron also modulated the number of $\mathrm{GFP}^{+}$cells (i.e., cells accumulating GFP following expression of the phlA$g f p$ fusion) in vitro, with a maximum relative green fluorescence (relative fluorescence units [RFU]) level at $2 \mu \mathrm{M}$ FeEDDHA (Fig. 1B). Lower and higher iron concentrations resulted in lower RFU levels, indicating a maximal activity of the phlA promoter at $2 \mu \mathrm{M}$ FeEDDHA in vitro. Similar results were found at a later sampling (42 h) or when repeating the experiment (not shown).

\section{Effect of clay mineralogy on iron bioavailability for $P$. protegens on roots in artificial soil.}

Ice nucleation activity of the iron-biosensor strain $P$. protegens Pf-5 pvd-inaZ, in which the iron-regulated promoter $p v d$ is fused to the promoterless ice nucleation reporter gene inaZ (Loper and Lindow 1994), was lower $(-57 \% ; P=0.008)$ at 7 days in tobacco rhizosphere samples from vermiculitic than illitic artificial soil (Fig. 2). Similar findings were made at other samplings (3 and 21 days). This means that rhizosphere bioavailability of iron for $P$. protegens was comparatively higher in the vermiculitic soil and, indeed, it was estimated at $3.0 \mu \mathrm{M} \mathrm{Fe}$ in the vermiculitic soil versus only $0.8 \mu \mathrm{M}$ in the illitic soil, based on data in Figure 2 and an in vitro standard curve (Supplementary Fig. S1). The ice nucleation activity of the positive control strain Pf-5 iceC (in which iceC is transcribed from its native iron-constitutive promoter) was comparable in both types of soil (Fig. 2).

\section{Effect of clay mineralogy on cell density and} phlA-gfp expression of $P$. protegens on roots in artificial soil.

Seven days after root inoculation of $P$. protegens $\mathrm{CHA} 0$ mche(pME7100) in the absence of T. basicola, the number of inoculant cells on tobacco roots was higher in the vermiculitic than the illitic soil based on microscopy analysis $(+35 \%$ number of total cells field ${ }^{-1}$ ) (Fig. 3A), with a similar trend $(+59 \%)$ by real-time PCR analysis but not significant at $P<0.05$ (Fig. 3D).

When expression of the phlA-gfp fusion was assessed at 7 days on tobacco roots in the absence of $T$. basicola, on one hand, the number of $\mathrm{GFP}^{+}$inoculant cells (i.e., green cells)
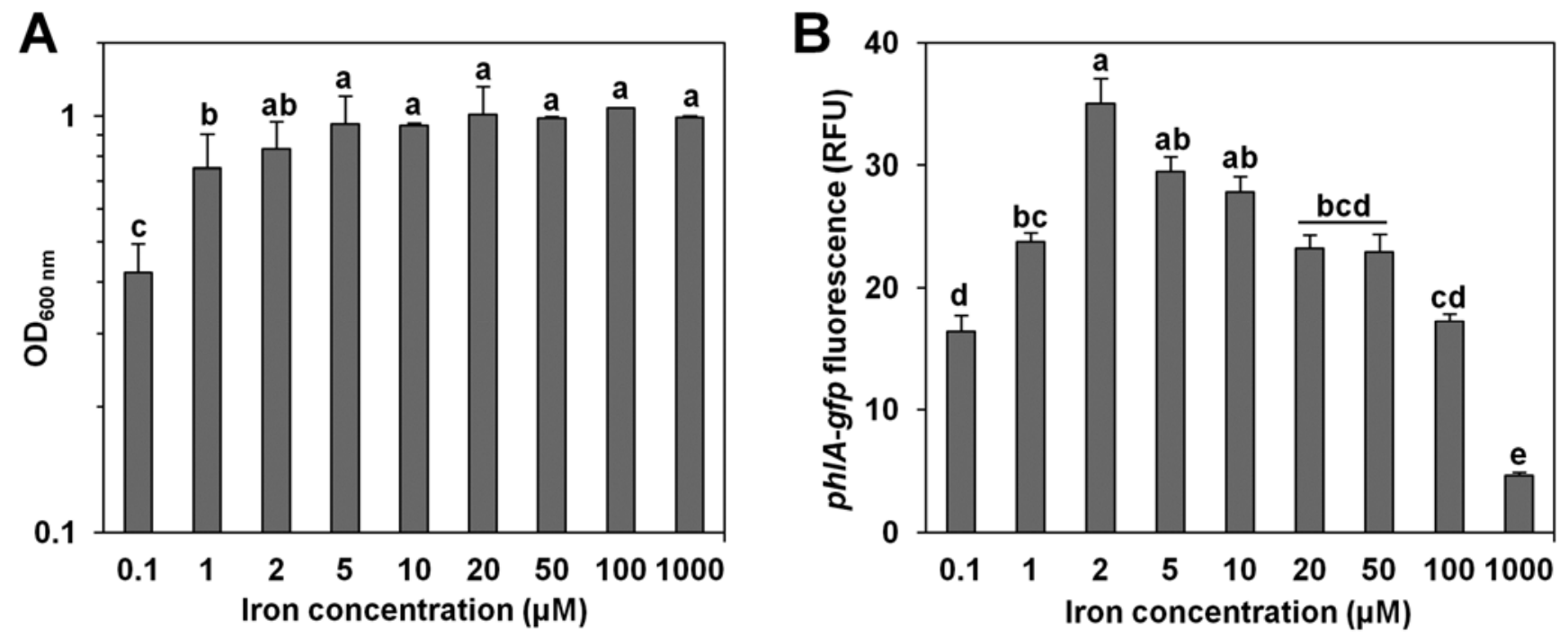

Fig. 1. Effect of nine iron concentrations (from 0.1 to $1,000 \mu \mathrm{M}$ FeEDDHA) on A, cell density (optical density at $600 \mathrm{~nm}\left[\mathrm{OD}_{600}\right]$ ) and $\mathbf{B}$, green fluorescent protein fluorescence levels (relative fluorescence units [RFU]) of Pseudomonas protegens CHA0-mche(pME7100) at 38 h (early stationary phase) in OSGly liquid medium. Means and standard errors are represented $(n=6)$. For each type of measurement, statistical relations between iron concentrations are shown using letters a to e (analysis of variance and Fisher's least significant difference tests; $P<0.05$ ). Similar results were obtained when measurements were taken at $42 \mathrm{~h}$. The experiment was run on two other occasions, with measurements taken at 38 and $42 \mathrm{~h}$, and similar results were obtained in all cases. 
was higher $(+63 \%)$ in the vermiculitic than the illitic soil (Fig. $3 \mathrm{~B})$. This resulted from a higher number of root-colonizing cells (discussed above) and a trend $(+21 \%$, but not significant at $P<0.05)$ for a higher proportion of $\mathrm{GFP}^{+}$cells in the vermiculitic soil (Fig. 3C). On the other hand, real-time PCR analysis of $p h l A-g f p$ expression on tobacco roots gave comparable $g f p$ mRNA (Fig. 3E) and relative $g f p$ mRNA levels (i.e., gfp mRNA/cell ratio) (Fig. 3F) in both soils.

\section{Effect of iron addition on cell density and phlA-gfp expression of $P$. protegens on roots in artificial illitic soil.}

To determine whether iron bioavailability in the tobacco rhizosphere was limiting for $p h l A-g f p$ expression in illitic soil, the effect of iron supplementation (2.4 mM FeEDDHA) was investigated in this soil. As expected, this enhanced the level of bioavailable iron, as indicated by a lower ice nucleation activity $(P<0.001)$ of the iron biosensor strain $P$. protegens $\mathrm{Pf}-5$ pvd-inaZ at 7 days (i.e., $-4.4 \pm 0.23 \log$ [ice nuclei cell ${ }^{-1}$ ] versus only $-1.6 \pm 0.09 \log$ [ice nuclei cell ${ }^{-1}$ ] in the nonamended illitic soil, corresponding to 8 and $0.8 \mu \mathrm{M}$ bioavailable Fe, respectively, estimated using a standard curve). Iron supplementation resulted in enhanced root colonization of tobacco roots by $P$. protegens $\mathrm{CHA} 0-m c h e(\mathrm{pME} 7100)$ at 7 days in illitic soil, based on higher total microscopy count of inoculant cells colonizing tobacco roots $(+119 \% ; P<0.001)$ (Fig. 4A) and higher

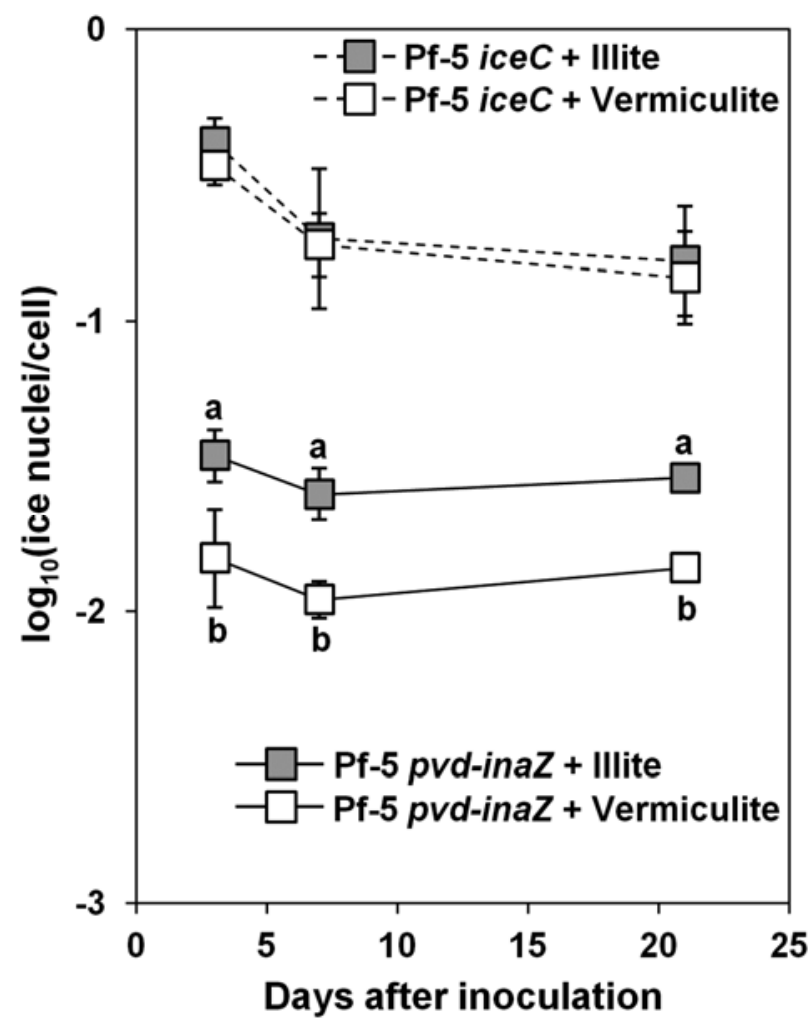

Fig. 2. Effect of clay mineralogy on ice nucleation activity of the iron biosensor strain Pseudomonas protegens Pf-5 pvd-inaZ and the positive control strain Pf-5 ice $C$ in the tobacco rhizosphere at 3, 7, and 21 days after transplanting of bacteria-inoculated seedlings in artificial vermiculitic (white bars) or illitic soil (gray bars). Ice nucleation activity was computed as the number of ice nuclei per cell (means \pm standard errors; $n=6$ plants). Ice nucleation activity of the positive control strain Pf-5 ice $C$ was the same in both soils at each sampling, as expected. The experiment was done twice (each time with three plants per treatment per sampling) with similar results, and results were pooled. For each strain, statistical differences between soils within each date are shown using letters a and b (Student's $t$ tests; $P<0.05)$. real-time PCR number of inoculant cells $(+78 \%, P=0.026)$ (Fig. 4D).

The number of $\mathrm{GFP}^{+}$cells of $P$. protegens CHA0mche(pME7100) on tobacco roots (expressed per microscopy field) at 7 days was higher following iron supplementation $(+190 \% ; P<0.001)$ (Fig. 4B). This resulted from a higher number of root-colonizing cells (discussed above) as well as a higher proportion $(+25 \% ; P=0.003)($ Fig. $4 \mathrm{C})$ of $\mathrm{GFP}^{+}$cells (i.e., proportion of green cells). Real-time PCR analysis of phlA-gfp expression on tobacco roots showed that iron supplementation had no effect on $g f p$ mRNA levels (Fig. 4E) but lowered relative $g f p$ mRNA levels $(-62 \% ; P=0.006)$ (Fig. 4F).

\section{Effect of clay mineralogy on cell density and} phlA-gfp expression of $P$. protegens on roots in artificial soil in the presence of $T$. basicola.

When system complexity was increased by introducing the phytopathogenic partner, it was important to verify that the genetic modifications done to $P$. protegens CHA0 had not abolished its ability to control black root rot. In the absence of bacterial inoculation, comparable black-root rot severity (i.e., percentage of root surface covered by $T$. basicola chlamydospores; approximately 23\%) was observed at 27 days in the vermiculitic and illitic artificial soils (Supplementary Table $\mathrm{S} 1)$. Inoculation of $P$. protegens $\mathrm{CHA} 0-m c h e(\mathrm{pME} 7100)$ resulted in lower black root-rot severity in the vermiculitic soil ( $8 \%$ severity). There was a similar trend in the illitic soil but it was not significant at $P<0.05$ and disease level remained as high as $17 \%$.

In OSGly minimal medium (Baehler et al. 2005), which contains $20 \mu \mathrm{M}$ FeEDDHA, $T$. basicola had no effect on cell density and phlA-gfp expression of $P$. protegens $\mathrm{CHA} 0-m c h e$ (pME7100) (data not shown). This was observed regardless of T. basicola inoculation level in the medium $\left(10^{2}\right.$ to $10^{4}$ endoconidia $\mathrm{ml}^{-1}$ ).

In both artificial soils, $T$. basicola inoculation affected cell density of $P$. protegens CHA0-mche(pME7100), because total microscopy cell counts were $25 \%$ lower (Fig. 3A) and realtime PCR counts at least $35 \%$ lower (Fig. 3D). With $T$. basicola inoculation, the number of $\mathrm{GFP}^{+}$cells of $P$. protegens CHA0-mche(pME7100) were more than 30\% lower than in the absence of the pathogen in both soils (Fig. 3B) but without any significant effect on the proportion of $\mathrm{GFP}^{+}$cells (Fig. 3C). Real-time PCR results showed comparable levels of $g f p$ mRNA in T. basicola-inoculated and noninoculated treatments (Fig. 3E), as well as a relative $g f p$ mRNA level higher upon $T$. basicola inoculation but only in the illitic soil (Fig. 3F).

In the presence of $T$. basicola, cell density of $P$. protegens CHA0-mche(pME7100) on roots was higher in the vermiculitic than the illitic soil based on microscopy analysis $(+33 \%$ number of total cells field ${ }^{-1}$ ) (Fig. 3A); however, this was not the case with real-time PCR data (Fig. 3D). In the presence of T. basicola, the number of $\mathrm{GFP}^{+}$cells on tobacco roots (expressed per microscopy field) was higher in the vermiculitic than the illitic soil (Fig. 3B), due to a higher cell density (discussed above) and a trend (not significant at $P<0.05$ ) for a higher proportion of $\mathrm{GFP}^{+}$cells (Fig. 3C). $g f p$ mRNA levels (Fig. 3E), as well as relative $g f p$ mRNA levels (Fig. 3F), did not differ significantly between the two T. basicola-inoculated artificial soils.

\section{Spatial patterns of $\boldsymbol{P}$. protegens colonization and phlA-gfp expression on roots.}

Confocal laser-scanning microscopy (CLSM) analysis showed that $P$. protegens $\mathrm{CHA} 0-m c h e(\mathrm{pME} 7100)$ colonized the three root zones (i.e., base, middle, and root tips), including 
both the root surface and root hairs (the latter found mostly in the root tip zone). In the illitic soil, iron addition resulted in higher numbers of inoculant cells at the root surface $(+143 \%)$ and on root hairs $(+66 \%)$, higher numbers of $\mathrm{GFP}^{+}$cells at the root surface $(+224 \%)$ and on root hairs $(+193 \%)$, and a higher proportion of $\mathrm{GFP}^{+}$cells on root hairs $(+60 \%)$ (Supplementary Table S2). At the root surface, samples from the vermiculitic soil displayed higher numbers of inoculant cells $(+62 \%)$ and higher numbers of $\mathrm{GFP}^{+}$cells $(+86 \%)$ but a comparable proportion of $\mathrm{GFP}^{+}$cells compared with the illitic soil. There was no difference between the two soils when considering root hairs. In the presence of T. basicola, however, the numbers of inoculant cells $(+46 \%)$ and of $\mathrm{GFP}^{+}$inoculant cells $(+151 \%)$, as well as the proportion of $\mathrm{GFP}^{+}$cells $(+59 \%)$, were higher in the vermiculitic than the illitic soil for root hairs. These effects were not significant at the root surface.

Because root systems can be heterogeneous, cell distribution was also considered in more details. In all experiments, $P$. protegens $\mathrm{CHA} 0-m c h e(\mathrm{pME7100)}$ was found as a mixture of individual cells, cell clumps (comprising 2 to 10 cells), and microcolonies ( $>10$ cells) (Supplementary Fig. S2A). The resulting cell distribution pattern differed between root surface and root hairs $\left(\chi^{2}\right.$ test of independence; $\left.P=10^{-17}\right)$, because the proportion of individual cells was larger (20 versus $12 \%)$ and that of microcolony cells was smaller (44 versus 62\%) on root hairs than at the root surface. In contrast, cell distribution patterns did not change significantly when comparing soil treatments (i.e., effect of clay mineral, iron addition, or T. basicola inoculation) or root zones (i.e., base, middle, or root tips). Similar findings were made when considering $\mathrm{GFP}^{+}$cells of $P$. protegens CHA0-mche(pME7100) (not shown).

\section{DISCUSSION}

The aim of this study was to assess the hypothesis that the bioavailability of iron and the expression of DAPG synthetic
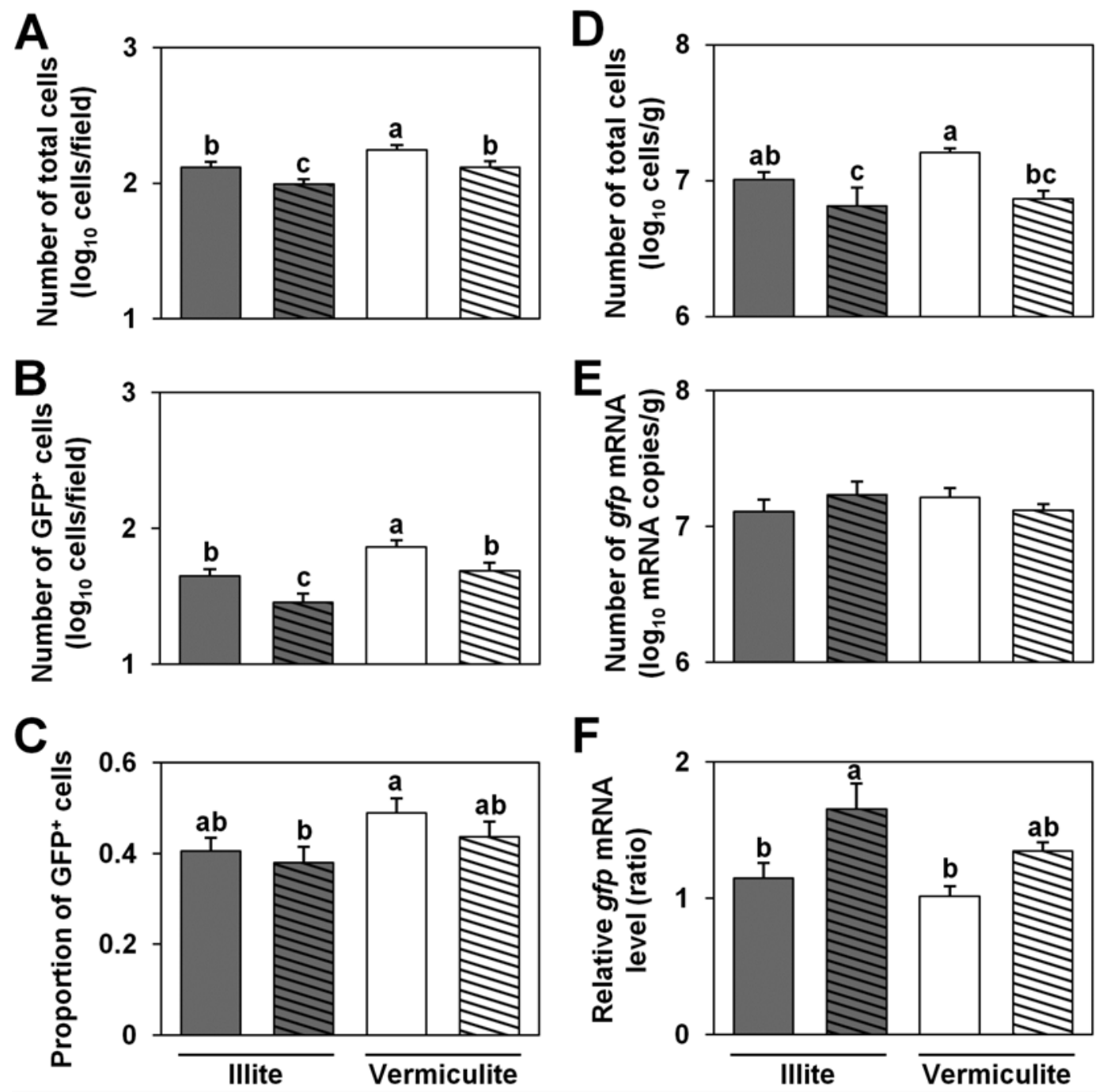

Fig. 3. Effect of clay mineralogy and inoculation with Thielaviopsis basicola ETH D127 $\left(10^{3}\right.$ endoconidia $\left.\mathrm{cm}^{-3}\right)$ on cell density and phlA-gfp expression of Pseudomonas protegens CHA0-mche(pME7100) in the tobacco rhizosphere at 7 days after transplanting of bacteria-inoculated seedlings in artificial vermiculitic (white bars) or illitic soil (gray bars). T. basicola inoculation is indicated by hatched lines. A, B, and $\mathbf{C}$, Confocal laser-scanning microscopy analysis of tobacco roots. Two experiments were conducted (giving similar results), each consisting of three plants per treatment and 10 confocal fields ( $225 \mu \mathrm{m}$ by 225 $\mu \mathrm{m}$ by $1 \mu \mathrm{m}^{3}$ per field) per plant. Pooled results from the two experiments are presented ( $n=60$ fields). For each field, the proportion of cells accumulating green fluorescent protein [GFP] following expression of the phlA-gfp fusion $\left(\mathrm{GFP}^{+}\right)$was calculated by dividing the number of green cells by the total number of fluorescent cells. D, E, and F, Real-time polymerase chain reaction analysis of tobacco roots. One of the experiments above was used, with five plants per treatment $(n=5)$. For each plant, the relative $g f p$ mRNA level was calculated by dividing the number of $g f p$ mRNA copies by the number of cells. In each of the six panels, means and standard errors are shown. Statistical differences between the four treatment combinations (illite versus vermiculite $\times$ T. basicolainoculated or not) are shown using letters a to $\mathrm{c}$ (two-factor analysis of variance and Fisher's least significant difference tests; $P<0.05$; the interaction between the two factors was not significant). 
genes for $P$. protegens in the tobacco rhizosphere are higher in the presence of vermiculite than illite clay, thereby substantiating the hypothesis that (suppressive) vermiculitic soils in Morens should provide more favorable conditions for iron acquisition and phl transcription by $P$. protegens compared with (conducive) illitic soils. Indeed, biosensor analyses indicated that both iron bioavailability for $P$. protegens and PhlA protein accumulation (number of $\mathrm{GFP}^{+}$cells) were higher in the vermiculitic than the illitic soil. Soil parent material determines many soil characteristics, including the type of clay mineral prevailing in the soil, yet the consequences for the functioning of rhizosphere microorganisms and plant-microbe interactions, which were important in the current case, are rarely studied (Almario et al. 2013; Ulrich and Becker 2006).

To determine the importance of iron bioavailability for $p h l A$ $g f p$ expression in $P$. protegens, iron addition was implemented in vitro, and it showed that the amount of bioavailable iron in

A
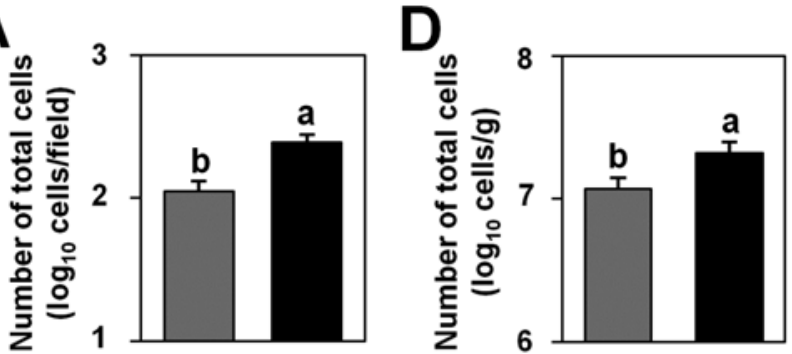

B
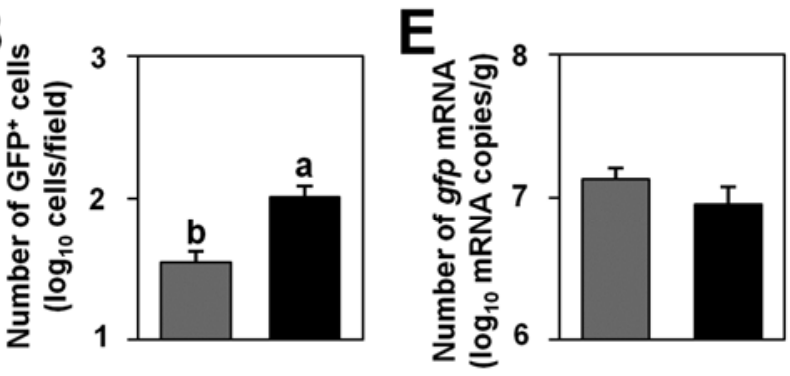

C

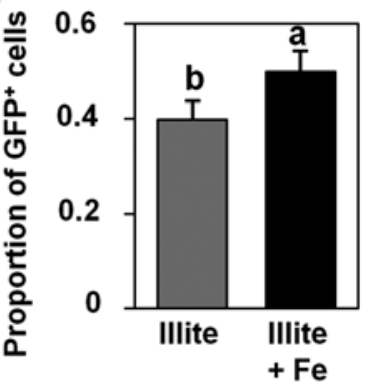

$\mathbf{F}$

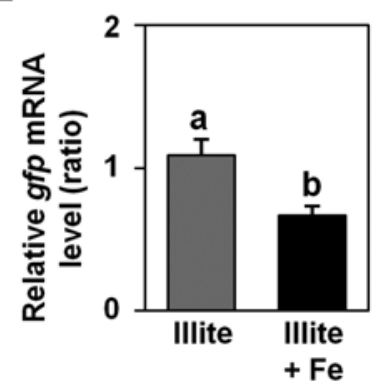

Fig. 4. Effect of iron addition (2.4 mM FeEDDHA) on cell density and phlA-gfp expression of Pseudomonas protegens CHA0-mche(pME7100) in the tobacco rhizosphere at 7 days after transplanting of bacteria-inoculated seedlings in artificial illitic soil. A, B, and C, Confocal laser-scanning microscopy analysis of tobacco roots. Two experiments were conducted (giving similar results), each consisting of three plants per treatment and 10 confocal fields $\left(225 \mu \mathrm{m}\right.$ by $225 \mu \mathrm{m}$ by $1 \mu^{3}$ per field $)$ per plant. Pooled results from the two experiments are presented ( $n=60$ fields). For each field, the proportion of cells accumulating green fluorescent protein [GFP] following expression of the phlA-gfp fusion $\left(\mathrm{GFP}^{+}\right)$was calculated by dividing the number of green cells by the total number of fluorescent cells. $\mathbf{D}, \mathbf{E}$, and $\mathbf{F}$, Real-time polymerase chain reaction analysis of tobacco roots. One of the experiments above was used, with five plants per treatment $(n=5)$. For each plant, the relative $g f p$ mRNA level was calculated by dividing the number of $g f p$ mRNA copies by the number of cells. In each of the six panels, means and standard errors are shown. Statistical differences between iron-amended (black bars) and nonamended soil (gray bars) are shown using letters a and b (Student's $t$ tests; $P<0.05$ ). vermiculitic soil (estimated at $3 \mu \mathrm{M} \mathrm{Fe}$ ) promoted $P$. protegens $\mathrm{CHA} 0$ growth in vitro and was close to the iron concentration inducing maximal phlA-gfp expression (i.e., $2 \mu \mathrm{M}$ ) (Fig. 1B). Indeed, similar positive effects on both features (especially at the root surface rather than on root hairs) were observed when the illitic soil was amended with iron at $2.4 \mathrm{mM}$ (thereby increasing iron bioavailability 10 times), a concentration raising plant-protecting activity of $P$. protegens $\mathrm{CHA} 0$ to levels found in vermiculitic soil (Keel et al. 1989; Voisard et al. 1989). These findings are compatible with the observation that iron deprivation affects $p h l$ transcription in P. protegens in vitro (Lim et al. 2012), and the hypothesis that higher iron availability in vermiculitic soils is required for disease suppression (Ramette et al. 2003).

The fact that $P$. protegens cells as well as $\mathrm{GFP}^{+}$cells at the root surface were much less abundant in the illitic soil than in high-iron soils (i.e., vermiculitic soil and iron-amended illitic soil) probably relates to the fact that iron deprivation affects several traits of importance for rhizosphere competence, besides phl transcription (Lim et al. 2012). Iron deprivation also limits cell motility (Lim et al. 2012) but this type of effect was not apparent when considering spatial patterns of $P$. protegens root colonization and GFP accumulation. Localized antimicrobial production by rhizobacteria at pathogen entry points is expected to underpin pathogen biocontrol (Fukui et al. 1994) but, here, phl transcription took place throughout the root system. This may be relevant for inhibition of T. basicola, because the latter does not display preferential sites of root penetration (e.g., it can infect root hairs as well as the root surface) (Hood and Shew 1997). It has been suggested that $P$. protegens $\mathrm{CHA} 0$ could also act by inducing ISR pathways in tobacco (Almario et al. 2013; Troxler et al. 1997), because $P$. protegens CHA0 delays but does not alter $T$. basicola infection patterns, and physical interaction between both microorganisms is not necessary for black root rot suppression (Troxler et al. 1997). Indeed, DAPG triggers ISR pathways in Arabidopsis (Weller et al. 2012). DAPG-triggered ISR requires a functional EIR1 gene (Iavicoli et al. 2003), which suggests that root tips, where this gene is expressed (Müller et al. 1998), might be a prime location to trigger ISR. However, cell distribution pattern of $P$. protegens on tobacco root tips did not differ in vermiculitic and illitic soils.

The numbers of cells and of $\mathrm{GFP}^{+}$cells (i.e., expressing phlA-gfp) of root-colonizing $P$. protegens $\mathrm{CHA} 0$ reached lower values when $T$. basicola was added (Fig. 3AB). Pathogen presence often increases cell density and expression of $p h l$ genes in $P$. protegens in other pathosystems, such as Rhizoctonia solani-bean (Jamali et al. 2009), Pythium ultimum-maize, or P. ultimum-cucumber (Notz et al. 2001). Phytopathogens may also counteract antagonistic fluorescent pseudomonads using different mechanisms (Duffy et al. 2003), ranging from survival inhibition by $P$. ultimum (Fedi et al. 1997) to fusaricacid-mediated repression of DAPG synthesis by $F$. oxysporum (Duffy and Défago 1997). Here, the negative effects of $T$. basicola on Pseudomonas protegens did not take place in vitro (i.e., in the absence of roots). Using a split-root system, Jousset and associates (2011) showed that infection of barley roots by Pythium ultimum promoted expression of $p h l$ genes in root-colonizing Pseudomonas protegens $\mathrm{CHA0}$, through a systemic effect on the plant. It might be that the effect of $T$. basicola on tobacco was also systemic, and further work will be needed to address this issue.

In this work, microscopy analysis of $\mathrm{GFP}^{+}$cells, which reflects GFP accumulation (GFP protein exhibiting a half-life of days) (Andersen et al. 1998) at the root microscale, was complemented by quantification of $g f p$ mRNA, which reflects recent $p h l A-g f p$ transcriptional activity (mRNA exhibiting half-lives of 
minutes) (Taniguchi et al. 2010) at the scale of the whole root system. Even though both measurements may not correlate, combining both provides additional insights (Taniguchi et al. 2010). Here, gfp mRNA levels were comparable in all treatments, whereas green fluorescence levels varied. This could entail i) phlA-gfp transcription levels that were not constant in space (i.e., with a number of transcripts that varied from one cell to the next) or in time or ii) the effect of post-transcriptional mechanisms (Taniguchi et al. 2010). Indeed, DAPG synthesis is subjected to Gac-mediated post-transcriptional upregulation (Haas and Défago 2005) and DAPG production was abolished in a gacA mutant despite $p h l$ transcription (Hassan et al. 2010). How differences in $p h l$ transcription translate in terms of DAPG synthesis under rhizosphere conditions remains to be quantified.

In the current work, differences in cell density of $P$. protegens CHA0 from one soil treatment to the next were of moderate magnitude (1.3- to 2.2-fold), as found when comparing root colonization of different cereal species (Rochat et al. 2010), and were lower than when comparing different plant species (de Werra et al. 2008; Notz et al. 2001). Similarly, the percentage of $\mathrm{GFP}^{+} P$. protegens cells varied little between soil treatments (from 36 to 50\%), as found between cereal species (Rochat et al. 2010). The percentage of $\mathrm{GFP}^{+}$P. protegens cells on tobacco roots was rather low in comparison with cereals, where it may reach 86 to $97 \%$ (Rochat et al. 2010). This is in accordance with the lower ability of dicotyledonous plants (such as tobacco) to promote expression of phl genes compared with monocots (Notz et al. 2001).

DAPG-producing pseudomonads correspond to at least seven Pseudomonas spp. from two main lineages (i.e., P. protegens and the 'P. fluorescens' complex) (Frapolli et al. 2007, 2012), which display differences in rhizosphere ecology (SharifiTehrani et al. 1998; Wang et al. 2001). P. protegens is a wellestablished model for analysis of Pseudomonas secondary metabolism (Kidarsa et al. 2011) and plant-protection mechanisms in Morens suppressive soils (Haas and Défago 2005) but species from the ' $P$. fluorescens' complex are also present in the tobacco rhizosphere in Morens soils (Frapolli et al. 2008, 2010), and ecological approaches at the scale of all DAPG-producing pseudomonads will be necessary to assess whether the current findings apply to all members of the functional group in Morens field soils. We carried out a preliminary assessment under nonsterile soil conditions but root colonization by $P$. protegens CHA0-mche(pME7100) was insufficient (approximately $5.5 \mathrm{log}$ per gram of root) for the microscopy and real-time RT-PCR methodology we used, with often no more than a few $\mathrm{GFP}^{+}$cells per microscopy field and real-time PCR of $g f p$ mRNA below detection limit, respectively. Additional method development will be necessary to achieve real-time PCR assessment of phl transcripts in natural populations of DAPG-producing pseudomonads combined with chemical analysis of DAPG production. In addition, biocontrol is often multifactorial (Haas and Défago 2005) and DAPG synthesis is not the only iron-regulated antagonistic function in P. protegens (Lim et al. 2012), which means that a broader assessment of biocontrol functions in root-colonizing Pseudomonas populations, and perhaps also in other plant-beneficial microbes (Kyselková et al. 2009), will be required to better understand black root rot suppressiveness of iron-rich vermiculitic Morens soil.

In conclusion, iron bioavailability for DAPG-producing $P$. protegens colonizing tobacco roots was higher in the presence of vermiculite than illite clay, and it translated to higher cell density and GFP accumulation (pointing to enhanced PhlA levels) in the rhizosphere in vermiculitic compared with illitic soil. These results substantiate the hypothesis that higher iron availability in vermiculitic (suppressive) than illitic (conducive) Morens soils can promote transcription of DAPG syn- thetic genes and black root rot control by pseudomonads in the tobacco rhizosphere.

\section{MATERIALS AND METHODS}

Microbial cultures and tobacco growth.

P. protegens CHA0-mche(pME7100) is a att $\operatorname{Tn} 7:: \operatorname{miniTn} 7-$ Gm- $\mathrm{P}_{\mathrm{tac}}-$ mcherry derivative of $P$. protegens $\mathrm{CHA0}$ that contains plasmid pME7100, in which a copy of the DAPG synthesis promoter phlA is fused to the promoterless reporter gene gfp (Rochat et al. 2010). The strain was cultured at $27^{\circ} \mathrm{C}$ on King's B agar (King et al. 1954) supplemented with gentamycin $\left(8 \mu \mathrm{g} \mathrm{ml}^{-1}\right)$ and tetracycline (for plasmid selection; $125 \mu \mathrm{g}$ $\mathrm{ml}^{-1}$ ). For $p h l A-g f p$ expression experiments, the strain was grown in $20 \mathrm{ml}$ of Luria-Bertani (LB) (Duchefa Biochemie BV, Haarlem, The Netherlands) broth supplemented with the same antibiotics at $27^{\circ} \mathrm{C}$ and $120 \mathrm{rpm}$. At $8 \mathrm{~h}, 1 \mathrm{ml}$ was used to inoculate $100 \mathrm{ml}$ of antibiotic-free LB broth and cells were grown at $27^{\circ} \mathrm{C}$ and $180 \mathrm{rpm}$. At $4 \mathrm{~h}, \log$-phase cells were harvested and washed twice with ultrapure sterile water, using $3,500 \times g$ and $23^{\circ} \mathrm{C}$ for $10 \mathrm{~min}$. The pellet was suspended in ultrapure sterile water and the $\mathrm{OD}_{600}$ was adjusted to 0.03 or 0.05 (i.e., $1.0 \times 10^{7}$ and $1.6 \times 10^{7}$ cells $\mathrm{ml}^{-1}$, respectively). The absence of fluorescence before inoculation was checked under a Zeiss Axioskope epifluorescence microscope (Carl Zeiss S.A.S., Oberkochen, Germany).

The iron-biosensor strain $P$. protegens Pf-5 pvd-inaZ (rifampicin and kanamycin resistant $\left[\mathrm{Rif}^{\mathrm{r}} \mathrm{Km}^{\mathrm{r}}\right]$ ) is $P$. protegens $\mathrm{Pf}-5$ carrying a plasmid in which the iron-regulated promoter $p v d$ is fused to the promoterless ice nucleation reporter gene inaZ (Loper and Lindow 1994). The positive control P. protegens Pf-5 ice $C\left(\right.$ Rif $\left.^{r} \mathrm{Km}^{\mathrm{r}}\right)$ is identical to strain Pf-5 pvd-inaZ except that ice $C$ is transcribed from its native iron-constitutive promoter (Loper and Lindow 1994). The two P. protegens strains were cultured at $27^{\circ} \mathrm{C}$ on King's B agar supplemented with rifampicin $\left(100 \mu \mathrm{g} \mathrm{ml}^{-1}\right)$ and kanamycin $\left(50 \mu \mathrm{g} \mathrm{ml}^{-1}\right)$. For gene expression experiments, strains were grown in $100 \mathrm{ml}$ of SM medium (Loper and Lindow 1987) supplemented with $10^{-1} \mathrm{M}$ $\mathrm{FeCl}_{3}$ at $27^{\circ} \mathrm{C}$ and $180 \mathrm{rpm}$. At $24 \mathrm{~h}$, stationary-phase cells were harvested and washed, the pellet was resuspended, and the $\mathrm{OD}_{600}$ adjusted to 0.015 or 0.10 (i.e., $1.0 \times 10^{7}$ and $6.7 \times$ $10^{7}$ cells $\mathrm{ml}^{-1}$, respectively), as indicated above.

T. basicola Ferraris strain ETH D127 (Berk. and Br.) was grown for 4 weeks in the dark on malt agar (Ramette et al. 2003). For inoculation, an endoconidial suspension adjusted to $10^{6}$ endoconidia $\mathrm{ml}^{-1}$ was prepared as described by Ramette and associates (2003).

Tobacco (Nicotiana glutinosa L.) was grown in a growth chamber at $22^{\circ} \mathrm{C}$ (day, $16 \mathrm{~h}$ ) and $18^{\circ} \mathrm{C}$ (night, $8 \mathrm{~h}$ ) at $70 \%$ relative humidity. Seed were surface disinfected in $70 \%$ ethanol for $1 \mathrm{~min}$ and $10 \% \mathrm{H}_{2} \mathrm{O}_{2}$ for $10 \mathrm{~min}$, then rinsed with ultrapure sterile water. They were then germinated on $1.6 \%$ water agar for 1 week before transferring onto $0.6 \%$ Knop's agar (Keel et al. 1989). At 4 weeks, four-leaf plants were removed and roots were washed aseptically in ultrapure sterile water before inoculation and transplanting into the soil systems.

\section{Soil systems.}

Artificial soil systems were prepared as described by Keel and associates (1989). Briefly, quartz sand of different grain sizes $(10 \% 1.5$ to $2.0 \mathrm{~mm}, 9.3 \% 0.8$ to $1.2 \mathrm{~mm}, 9.3 \% 0.5$ to $0.75 \mathrm{~mm}, 28.6 \% 0.10$ to $0.50 \mathrm{~mm}$, and $42.8 \% 0.08$ to 0.20 $\mathrm{mm})$ was mixed with quartz powder $(55 \%<40 \mu \mathrm{m})$ and clay (vermiculite or illite), in a 70:20:10 weight ratio. The artificial soils were autoclaved, moistened with ultrapure sterile water (10\% [vol/wt] for vermiculite and $5 \%$ [vol/wt] for illite), and $20 \mathrm{~g}$ was used to fill $42-\mathrm{cm}^{3}$ containers. When indicated, soil 
was amended with $2.4 \mathrm{mM}$ FeEDDHA ( $\mathrm{Fe}^{3+}$ at $9.9 \mu \mathrm{g} \mathrm{g}^{-1}$ dry soil) (Keel et al. 1989) or inoculated with T. basicola at $10^{3}$ endoconidia $\mathrm{cm}^{-3}$. After transplanting, $1.1 \mathrm{ml}$ of Knop's plant nutrient solution was added per container, water content was adjusted to $70 \%$ soil water-holding capacity (i.e., $20 \%$ [wt/wt] for vermiculitic soil and $15 \%$ [wt/wt] for illitic soil) with ultrapure sterile water, and the containers were sealed with porous sterile adhesive tape (Micropore Surgical Tape; 3M, Borken, Germany). No further watering was necessary except for the longer (27 days) biocontrol experiment, where soil water content was maintained by watering the pots every week.

\section{Biocontrol activity of $P$. protegens CHA0-mche(pME7100) in artificial soils.}

To compare the biocontrol activity of $P$. protegens $\mathrm{CHA} 0$ $m c h e(\mathrm{pME7100})$ in the vermiculitic and the illitic artificial soils, 10 plants per soil (each plant in a separate container) were either inoculated with $T$. basicola, $P$. protegens $\mathrm{CHA0}$ $m c h e(\mathrm{pME} 7100)$, or both or were not inoculated, as indicated below. At 27 days, black root rot severity (i.e., percentage of root surface covered by $T$. basicola chlamydospores) was scored using a height-class disease scale (Stutz et al. 1986).

\section{Monitoring of $p h l A-g f p$ in vitro \\ in response to iron or $T$. basicola.}

The experiment was carried out as described by Baehler and associates (2005). In all, $3.3 \times 10^{5}$ cells of $P$. protegens $\mathrm{CHA} 0$ mche(pME7100) were inoculated in $10 \mathrm{ml}$ of OSGly medium (Baehler et al. 2005) containing i) 0.1 to $1,000 \mu \mathrm{M}$ FeEDDHA or ii) $20 \mu \mathrm{M}$ FeEDDHA and T. basicola at $10^{2}$ to $10^{4}$ endoconidia $\mathrm{ml}^{-1}$. For each treatment, $200 \mu \mathrm{l}$ were placed (in six replicates) in a 96-well microtitration plate with flat transparent bottom (Greiner Bio-one, Frickenhausen, Germany) and the plate was incubated for $42 \mathrm{~h}$ at $30^{\circ} \mathrm{C}$ with orbital shaking $(500$ $\mathrm{rpm}$ ). Green fluorescence (excitation $480 \mathrm{~nm}$, emission $520 \mathrm{~nm}$ ), red fluorescence (excitation $587 \mathrm{~nm}$, emission $661 \mathrm{~nm}$ ), and absorbance (at $600 \mathrm{~nm}$ ) were measured every $2 \mathrm{~h}$ in a Xenius microplate reader spectrofluorometer (SAFAS, Monaco). For each individual measurement, fluorescence value was divided by the corresponding $\mathrm{OD}_{600}$ value and the resulting specific fluorescence level expressed as RFU. The experiment was done twice with similar results.

\section{CLSM monitoring of $p h l A-g f p$ in the tobacco rhizosphere.}

Tobacco root systems were inoculated by dipping for $1 \mathrm{~h}$ in a cell suspension $\left(\mathrm{OD}_{600}=0.03\right.$; approximately $10^{7}$ cells $\mathrm{ml}^{-1}$ ) of $P$. protegens CHA0-mche(pME7100), and seedlings were transplanted into artificial soil, as described above. At 7 days, plants were unearthed and roots were washed in ultrapure sterile water, mounted in Aqua-Poly/Mount (Polysciences, Eppelheim, Germany), and examined immediately by CLSM using a 510 Meta microscope (Carl Zeiss S.A.S.) equipped with an argon-krypton laser, as well as detectors and filter sets for green (i.e., $488 \mathrm{~nm}$ for excitation and 505 to $550 \mathrm{~nm}$ for detection) and red (i.e., $543 \mathrm{~nm}$ for excitation and $>585 \mathrm{~nm}$ for detection) fluorescence. After acquisition of the transmitted image (in bright-field mode at $\times 400$ magnification), the three single-color images were overlaid as a single image using LSM software (release 4.2; Carl Zeiss S.A.S.). Three root systems were analyzed per treatment, 10 images per root system were taken, and the whole experiment was done twice.

\section{RNA/DNA extraction and real-time PCR quantification of bacterial cells and $\boldsymbol{g} f \boldsymbol{p}$ mRNA.}

For real-time PCR and RT-PCR, the roots of five plants inoculated with $P$. protegens CHA0-mche(pME7100) were collected in each treatment, washed in ultrapure sterile water, and immediately frozen in liquid nitrogen. Noninoculated plants were used as negative controls. After grinding the roots in liquid nitrogen using a pestle, nucleic acids were extracted using the protocol of Griffiths and associates (2000), as modified by Almario and associates (2013), and were suspended in $100 \mu \mathrm{l}$ of RNase-free water.

Cells of $P$. protegens $\mathrm{CHA} 0$ were quantified according to von Felten and associates (2010). Real-time PCR was done directly from 10- $\mu$ l samples of nucleic acids (diluted five times), using $0.5 \mu \mathrm{M}$ primers CHA0_1_for (5'-CGACACATGACCA ACATCGTTCGA-3') and CHA 0 _1_rev (5'-GGCTACAAGGT CATTACAAAATCCAGTGAT-3'), which target a strain-specific sequence-characterized amplified region marker (von Felten et al. 2010). A LightCycler 480 (Roche Applied Science, Meylan, France) was used according to the manufacturer's instructions. An external standard curve generated from genomic DNA of $P$. protegens CHAO (obtained using the NucleoSpin Tissue kit; Macherey-Nagel, Hoerdt, France) was used for estimation of cell number in uncharacterized DNA samples. Amplification specificity was checked by melting curve analysis and gel electrophoresis of the amplification product. DNA samples were analyzed in triplicate and the mean cycle threshold $(\mathrm{Ct})$ value was reported in the external standard curve to infer cell number in the sample.

For $g f p$ mRNA quantification, a 40- $\mu$ l sample of nucleic acids was treated with DNase I (Invitrogen, Cergy Pontoise, France) according to the manufacturer's instructions, and RNA was purified and eluted in $100 \mu \mathrm{l}$ of RNase-free water using the RNeasy kit (Qiagen, Courtaboeuf, France). Because one DNase I treatment was insufficient to eliminate all DNA contamination, a second treatment was performed on the purified RNA sample. Finally, RNA was precipitated for $30 \mathrm{~min}$ at room temperature using 1 volume of isopropanol, pelleted by centrifuging the tubes for $15 \mathrm{~min}$ at $16,000 \times g$ and $4^{\circ} \mathrm{C}$, and resuspended in 60 $\mu l$ of RNase-free water. Reverse transcription for $g f p$ cDNA synthesis was performed using $15 \mu \mathrm{l}$ of RNA primer RTgfpR (5'-CTCTTTTCGTTGGGATCTTTCG-3') (Baehler et al. 2005) at $0.1 \mu \mathrm{M}$ and the Omniscript RT kit (Qiagen), following the manufacturer's instructions. $g f p$ cDNA was subsequently purified using the MinElute purification kit (Qiagen) and used in real-time PCR. A negative control (i.e., the same but without reverse transcriptase) was also studied for each sample. Realtime PCR quantification of $g f p$ cDNA was conducted following the protocol of Baehler and associates (2005) using $g f p$ primers RTgfpF (5'-CCTGTCCTTTTACCAGACAACCA-3') and RTgfpR at $0.5 \mu \mathrm{M}$ in a LightCycler 480 (Roche Applied Science), according to the manufacturer's instructions. An external gfp standard curve generated from plasmid pME7100 (obtained using the NucleoSpin Plasmid kit; Macherey-Nagel) was used for estimation of $g f p$ copy number in uncharacterized cDNA samples. Amplification specificity was checked by melting curve analysis and gel electrophoresis of the amplification product. cDNA samples were analyzed in triplicate and the mean $\mathrm{Ct}$ value was reported in the external standard curve to infer $g f p$ cDNA copy number in the sample.

\section{Assessment of iron bioavailability in vitro and in the tobacco rhizosphere.}

The response of the iron-biosensor $P$. protegens $\mathrm{Pf}-5 \mathrm{pvd}$ inaZ to increasing iron concentrations in vitro was assessed as described by Loper and Henkels (1997). The strain $\left(6.6 \times 10^{6}\right.$ cells) was inoculated into $20 \mathrm{ml}$ of SM medium containing 0.1 to $1,000 \mu \mathrm{M}$ FeEDDHA. Three 5-ml aliquots per concentration were incubated for $48 \mathrm{~h}$ at $20^{\circ} \mathrm{C}$ and $120 \mathrm{rpm}$ before measuring ice nucleation activity. To this end, the number of ice nuclei was determined by the droplet freezing assay (Loper and Lindow 1997), after serially diluting samples and placing 
40 droplets of $10 \mu \mathrm{l}$ from each dilution on a paraffin-coated aluminum foil floating on a $-5^{\circ} \mathrm{C}$ ethanol bath and recording the number of frozen droplets after $2 \mathrm{~min}$. The number of ice nuclei was computed as $\ln [1 /(1$ - fraction of frozen droplets $)] /$ [droplet volume $\times$ dilution], as proposed by Vali (1971), and was divided by the number of cells (estimated via $\mathrm{OD}_{600}$ measurement). A standard curve was generated by plotting the ice nucleation activity (ice nuclei cell ${ }^{-1}$ ) against the FeEDDHA concentration.

To assess iron bioavailability in the tobacco rhizosphere, root systems were inoculated as indicated above, by dipping for $1 \mathrm{~min}$ in a cell suspension $\left(\mathrm{OD}_{600} 0.015\right.$, approximately $10^{7}$ cells $\mathrm{ml}^{-1}$ ) of the iron biosensor strain Pf-5 pvd-inaZ or the positive control strain Pf-5 iceC. The tobacco seedlings were then transplanted in the artificial soils. Seven days later, plants were unearthed. Each root system and adhering soil was placed in $1 \mathrm{ml}$ of $10 \mathrm{mM}$ potassium phosphate buffer ( $\mathrm{pH} \mathrm{7.0)}$ and sonicated for $5 \mathrm{~min}$. Samples were serially diluted, cell numbers were determined 2 days after plating onto King's B medium supplemented with rifampicin and kanamycin, and ice nucleation activity was determined (as indicated above). Ice nucleation activity of the positive control strain Pf-5 iceC was constant in all treatments. Three plants were studied per soilstrain combination. The experiment was done twice.

\section{Image and statistical analyses.}

The cell counting option of BioImage_L software v.2.1 (Chávez de Paz 2009) with a noise correction set to default was used to quantify each type of fluorescent cells per CLSM image. The proportion of cells that expressed the phlA-gfp fusion and produced GFP (i.e., proportion of $\mathrm{GFP}^{+}$cells) was calculated as the number of green cells divided by the total number of fluorescent cells in the image.

The root colonization pattern of bacteria was studied by recording for each CLSM image i) the corresponding root zone (i.e., the root base [first third], the middle part [second third], or the root tip [third third]), ii) the location of bacterial cells (root surface or root hair), and iii) the size of each bacterial colony detected, using the particle size analysis option in ImageJ software.

Statistical analyses were performed without data transformation (for disease severity) or after square root (for proportions), rank (for bacterial colony size), or $\log _{10}$ (for all other variables) transformation. Means were compared by Student's $t$ tests, or by analysis of variance followed with Fisher's least significant difference tests when more than two treatments were studied. Size distribution patterns of bacterial cells (i.e., the proportion of individual cells, cell clumps, and microcolonies) were compared using a $\chi^{2}$ test of independence. Analyses were carried out at $P<0.05$, using the R environment.

\section{ACKNOWLEDGMENTS}

We thank J. Loper (Oregon State University), C. Keel (Université de Lausanne), and A. Jousset (University of Goettingen) for the gift of strains; M. Maurhofer (ETH Zurich) for providing artificial soils and useful discussions; G. Défago (ETH Zurich) for useful discussions; and D. Desbouchages (Université Lyon 1) for technical help. This work was supported by the Ministère Français de la Recherche, and made use of the FR41 technical platforms DTAMB, Serre, and Centre Technologique des Microstructures at Université Lyon 1.

\section{LITERATURE CITED}

Almario, J., Moënne-Loccoz, Y., and Muller, D. 2013. Monitoring of the relation between 2,4-diacetylphloroglucinol-producing Pseudomonas and Thielaviopsis basicola populations by real-time PCR in tobacco black root-rot suppressive and conducive soils. Soil Biol. Biochem. 57:144-155
Andersen, J. B., Sternberg, C., Poulsen, L. K., Bjørn, S. P., Givskov, M., and Molin, S. 1998. New unstable variants of green fluorescent protein for studies of transient gene expression in bacteria. Appl. Environ. Microbiol. 64:2240-2246.

Baehler, E., Bottiglieri, M., Péchy-Tarr, M., Maurhofer, M., and Keel, C. 2005. Use of green fluorescent protein-based reporters to monitor balanced production of antifungal compounds in the biocontrol agent Pseudomonas fluorescens CHA0. J. Appl. Microbiol. 99:24-38.

Chávez de Paz, L. E. 2009. Image analysis software based on color segmentation for characterization of viability and physiological activity of biofilms. Appl. Environ. Microbiol. 75:1734-1739.

Combes-Meynet, E., Pothier, J. F., Moënne-Loccoz, Y., and PrigentCombaret, C. 2011. The Pseudomonas secondary metabolite 2,4-diacetylphloroglucinol is a signal inducing rhizoplane expression of Azospirillum genes involved in plant-growth promotion. Mol. PlantMicrobe Interact. 24:271-284.

Couillerot, O., Prigent-Combaret, C., Caballero-Mellado, J., and MoënneLoccoz, Y. 2009. Pseudomonas fluorescens and closely-related fluorescent pseudomonads as biocontrol agents of soil-borne phytopathogens. Lett. Appl. Microbiol. 48:505-512.

de Werra, P., Baehler, E., Huser, A., Keel, C., and Maurhofer, M. 2008. Detection of plant-modulated alterations in antifungal gene expression in Pseudomonas fluorescens CHA0 on roots by flow cytometry. Appl. Environ. Microbiol. 74:1339-1349.

Dowling, D. N., Sexton, R., Fenton, A., Delany, I., Fedi, S., McHugh, B., Callanan, M., Moënne-Loccoz, Y., and O'Gara, F. 1996. Iron regulation in plant-associated Pseudomonas fluorescens M114: Implications for biological control. Pages 502-511 in: Molecular Biology of Pseudomonads, Chapter 44. T. Nakazawa, K. Furukawa, D. Haas, and S. Silver, eds. ASM Press, Washington, DC.

Duffy, B. K., and Défago, G. 1997. Zinc improves biocontrol of Fusarium crown and root rot of tomato by Pseudomonas fluorescens and represses the production of pathogen metabolites inhibitory to bacterial antibiotic biosynthesis. Phytopathology 87:1250-1257.

Duffy, B. K., and Défago, G. 1999. Environmental factors modulating antibiotic and siderophore biosynthesis by Pseudomonas fluorescens biocontrol strains. Appl. Environ. Microbiol. 65:2429-2438.

Duffy, B. K., Schouten, A., and Raaijmakers, J. M. 2003. Pathogen self defense: Mechanisms to counteract microbial antagonism. Annu. Rev. Phytopathol. 41:501-538.

Fedi, S., Tola, E., Moënne-Loccoz, Y., Dowling, D. N., Smith, L. M., and O'Gara, F. 1997. Evidence for signaling between the phytopathogenic fungus Pythium ultimum and Pseudomonas fluorescens F113: P. ultimum represses the expression of genes in P. fluorescens F113, resulting in altered ecological fitness. Appl. Environ. Microbiol. 63:4261-4266.

Frapolli, M., Défago, G., and Moënne-Loccoz, Y. 2007. Multilocus sequence analysis of biocontrol fluorescent Pseudomonas spp. producing the antifungal compound 2,4-diacetylphloroglucinol. Environ. Microbiol. 9:1939-1955.

Frapolli, M., Moënne-Loccoz, Y., Meyer, J., and Défago, G. 2008. A new DGGE protocol targeting 2,4-diacetylphloroglucinol biosynthetic gene phlD from phylogenetically contrasted biocontrol pseudomonads for assessment of disease-suppressive soils. FEMS (Fed. Eur. Microbiol. Soc.) Microbiol. Ecol. 64:468-481.

Frapolli, M., Défago, G., and Moënne-Loccoz, Y. 2010. Denaturing gradient gel electrophoretic analysis of dominant 2,4-diacetylphloroglucinol biosynthetic phlD alleles in fluorescent Pseudomonas from soils suppressive or conducive to black root rot of tobacco. Soil Biol. Biochem. 42:649-656.

Frapolli, M., Pothier, J. F., Défago, G., and Moënne-Loccoz, Y. 2012. Evolutionary history of synthesis pathway genes for phloroglucinol and cyanide antimicrobials in plant-associated fluorescent pseudomonads. Mol. Phylogenet. Evol. 63:877-890.

Fukui, R., Schroth, M. N., Hendson, M., Hancock, J. G., and Firestone, M. K. 1994. Growth patterns and metabolic activity of pseudomonads in sugar beet spermospheres: Relationship to pericarp colonization by Pythium ultimum. Phytopathology 84:1331-1338.

Griffiths, R. I., Whiteley, A. S., O’Donnell, A. G., and Bailey, M. J. 2000. Rapid method for coextraction of DNA and RNA from natural environments for analysis of ribosomal DNA- and rRNA-based microbial community composition. Appl. Environ. Microbiol. 66:54885491.

Haas D., and Défago, G. 2005. Biological control of soil-borne pathogens by fluorescent pseudomonads. Nat. Rev. Microbiol. 3:307-319.

Hassan, K. A., Johnson, A., Shaffer, B. T., Ren, Q., Kidarsa, T. A., Elbourne, L. D. H., Hartney, S., Duboy, R., Goebel, N. C., Zabriskie, T. M., Paulsen, I. T., and Loper, J. E. 2010. Inactivation of the GacA response regulator in Pseudomonas fluorescens Pf-5 has far-reaching transcriptomic consequences. Environ. Microbiol. 12:899-915.

Hood, M. E., and Shew, H. D. 1997. Initial cellular interactions between 
Thielaviopsis basicola and tobacco root hairs. Phytopathology 87:228235

Iavicoli, A., Boutet, E., Buchala, A., and Métraux, J. P. 2003. Induced systemic resistance in Arabidopsis thaliana in response to root inoculation with Pseudomonas fluorescens CHA0. Mol. Plant-Microbe Interact. 16:851-858

Jamali, F., Sharifi-Tehrani, A., Lutz, M. P., and Maurhofer, M. 2009. Influence of host plant genotype, presence of a pathogen, and coinoculation with Pseudomonas fluorescens strains on the rhizosphere expression of hydrogen cyanide and 2,4-diacetylphloroglucinol biosynthetic genes in P. fluorescens biocontrol strain CHA0. Microbial Ecol. 57:267-275.

Jousset, A., Rochat, L., Lanoue, A., Bonkowski, M., Keel, C., and Scheu, S. 2011. Plants respond to pathogen infection by enhancing the antifungal gene expression of root-associated bacteria. Mol. Plant-Microbe Interact. 24:352-358.

Keel, C., Voisard, C., Berling, C. H., Kahr, G., and Défago, G. 1989. Iron sufficiency, a prerequisite for the suppression of tobacco black root rot by Pseudomonas fluorescens strain CHA0 under gnotobiotic conditions. Phytopathology 79:584-589.

Keel, C., Schnider, U., Maurhofer, M., Voisard, C., Laville, J., Burger, U., Wirthner, P., Haas, D., Défago, G. 1992. Suppression of root diseases by Pseudomonas fluorescens CHA0: Importance of the bacterial secondary metabolite 2,4-diacetylphloroglucinol. Mol. Plant-Microbe Interact. 5:4-13.

Kidarsa, T. A., Goebel, N. C., Zabriskie, T. M., and Loper, J. E. 2011. Phloroglucinol mediates cross-talk between the pyoluteorin and 2,4diacetylphloroglucinol biosynthetic pathways in Pseudomonas fluorescens Pf-5. Mol. Microbiol. 81:395-414.

King, E. O., Ward, M. K., and Raney, D. E. 1954. Two simple media for the demonstration of pyocyanin and fluorescein. J. Lab. Clin. Med. 44:301-307.

Kyselková, M., and Moënne-Loccoz, Y., 2012. Pseudomonas and other microbes in disease-suppressive soils. Pages 93-140 in: Sustainable Agriculture Reviews, Vol. 9: Organic Fertilisation, Soil Quality and Human Health. E. Lichtfouse, ed. Springer, Dordrecht, The Netherlands.

Kyselková, M., Kopecký, J., Frapolli, M., Défago, G., Ságová-Marečková, M., Grundmann, G. L., and Moënne-Loccoz, Y. 2009. Comparison of rhizobacterial community composition in soil suppressive or conducive to tobacco black root rot disease. ISME J. 3:1127-1138.

Landa, B. B., Mavrodi, O. V., Raaijmakers, J. M., McSpadden Gardener, B. B., Thomashow, L. S., and Weller, D. M. 2002. Differential ability of genotypes of 2,4-diacetylphloroglucinol-producing Pseudomonas fluorescens strains to colonize the roots of pea plants. Appl. Environ. Microbiol. 68:3226-3237.

Lim, C. K., Hassan, K. A., Tetu, S. G., Loper, J. E., and Paulsen, I. T. 2012. The effect of iron limitation on the transcriptome and proteome of Pseudomonas fluorescens Pf-5. PLoS ONE 7:e39139. doi:10.1371/ journal.pone.0039139. Published online.

Loper, J. E., and Henkels, M. D. 1997. Availability of iron to Pseudomonas fluorescens in rhizosphere and bulk soil evaluated with an ice nucleation reporter gene. Appl. Environ. Microbiol. 63:99-105.

Loper, J. E., and Lindow, S. E. 1987. Lack of evidence for in situ fluorescent pigment production by Pseudomonas syringae pv. syringae on bean leaf surfaces. Phytopathology 77:1449-1454.

Loper, J. E., and Lindow, S. E. 1994. A biological sensor for iron available to bacteria in their habitats on plant surfaces. Appl. Environ. Microbiol. 60:1934-1941.

Loper, J. E., and Lindow, S. E. 1997. Reporter gene systems useful in evaluating in situ gene expression by soil- and plant-associated bacteria. Pages 482-492 in: Manual of Environmental Microbiology. C. J. Hurst, G. R. Knudsen, M. J. McInerney, L. D. Stetzenbach, and M. V. Walter, eds. ASM Press, Washington, DC.

Lutz, M. P., Wenger, S., Maurhofer, M., Défago, G., and Duffy, B. 2004. Signaling between bacterial and fungal biocontrol agents in a strain mixture. FEMS (Fed. Eur. Microbiol. Soc.) Microbiol. Ecol. 48:447-455.

Müller, B. 2009. Impact of the bacterium Pseudomonas fluorescens and its genetic derivatives on vermiculite: Effects on trace metals contents and clay mineralogical properties. Geoderma 153:94-103.

Müller, A., Guan, C., Gälweiler, L., Tänzler, P., Huijser, P., Marchant, A., Parry, G., Bennett, M., Wisman, E., and Palme, K. 1998. AtPIN2 defines a locus of Arabidopsis for root gravitropism control. EMBO (Eur. Mol. Biol. Organ.) J. 17:6903-6911.

Notz, R., Maurhofer, M., Schnider-Keel, U., Duffy, B., Haas, D., and Défago, G. 2001. Biotic factors affecting expression of the 2,4-diacetylphloroglucinol biosynthesis gene phlA in Pseudomonas fluorescens biocontrol strain CHA0 in the rhizosphere. Phytopathology 91:873-881.
Raaijmakers, J. M., Paulitz, T. C., Steinberg, C., Alabouvette, C., and Moënne-Loccoz, Y. 2009. The rhizosphere: A playground and battlefield for soilborne pathogens and beneficial microorganisms. Plant Soil 321:341-361.

Ramette, A., Moënne-Loccoz, Y., and Défago, G. 2003. Prevalence of fluorescent pseudomonads producing antifungal phloroglucinols and/or hydrogen cyanide in soils naturally suppressive or conducive to tobacco black root rot. FEMS (Fed. Eur. Microbiol. Soc.) Microbiol. Ecol. 44:35-43.

Ramette, A., Moënne-Loccoz, Y., and Défago, G. 2006. Genetic diversity and biocontrol potential of fluorescent pseudomonads producing phloroglucinols and hydrogen cyanide from Swiss soils naturally suppressive or conducive to Thielaviopsis basicola-mediated black root rot of tobacco. FEMS (Fed. Eur. Microbiol. Soc.) Microbiol. Ecol. 55:369-381.

Rochat, L., Péchy-Tarr, M., Baehler, E., Maurhofer, M., and Keel, C. 2010. Combination of fluorescent reporters for simultaneous monitoring of root colonization and antifungal gene expression by a biocontrol pseudomonad on cereals with flow cytometry. Mol. Plant-Microbe Interact. 23:949-961.

Sharifi-Tehrani, A., Zala, M., Natsch, A., Moënne-Loccoz, Y., and Défago, G. 1998. Biocontrol of soil-borne fungal plant diseases by 2,4-diacetylphloroglucinol-producing fluorescent pseudomonads with different restriction profiles of amplified 16S rDNA. Eur. J. Plant Pathol. 104:631-643

Stutz, E., Défago, G., Hantke, R., and Kern, H. 1985. Effect of parent materials derived from different geological strata on suppressiveness of soils to black root rot of tobacco. Pages 215-217 in: Ecology and Management of Soilborne Plant Pathogens. C. A. Parker, A. D. Rovira, K. J. Moore, P. T. W. Wong, J. F. Kollmorgen, eds. American Phytopathological Society, St. Paul, MN

Stutz, E. W., Défago, G., and Kern, H. 1986. Naturally-occurring fluorescent Pseudomonas involved in suppression of black root-rot of tobacco. Phytopathology 76:181-185.

Stutz, E. W., Kahr, G., and Défago, G. 1989. Clays involved in suppression of tobacco black root-rot by a strain of Pseudomonas fluorescens. Soil Biol. Biochem. 21:361-366.

Taniguchi, Y., Choi, P. J., Li, G. W., Chen, H., Babu, M., Hearn, J., Emili, A., and Xie, X. S. 2010. Quantifying E. coli proteome and transcriptome with single-molecule sensitivity in single cells. Science 329:533538.

Troxler, J., Berling, C. H., Moënne-Loccoz, Y., Keel, C., and Défago, G. 1997. Interactions between the biocontrol agent Pseudomonas fluo rescens $\mathrm{CHA0}$ and Thielaviopsis basicola in tobacco roots observed by immunofluorescence microscopy. Plant Pathol. 46:62-71.

Ulrich, A., Becker, R., 2006. Soil parent material is a key determinant of the bacterial community structure in arable soils. FEMS (Fed. Eur. Microbiol. Soc.) Microbiol. Ecol. 56:430-443.

Vali, G. 1971. Quantitative evaluation of experimental results on heterogeneous freezing nucleation of supercooled liquids. J. Atmos. Sci. 28:402 409.

Voisard, C., Keel, C., Haas, D., and Défago, G. 1989. Cyanide production by Pseudomonas fluorescens helps suppress black root rot of tobacco under gnotobiotic conditions. EMBO (Eur. Mol. Biol. Organ.) J. 8:351358.

von Felten, A., Défago, G., and Maurhofer, M. 2010. Quantification of Pseudomonas fluorescens strains F113, CHA0 and Pf153 in the rhizosphere of maize by strain-specific real-time PCR unaffected by the variability of DNA extraction efficiency. J. Microbiol. Methods 81:108115.

Wang, C., Ramette, A., Punjasamarnwong, P., Zala, M., Natsch, A., Moënne-Loccoz, Y., and Défago, G. 2001. Cosmopolitan distribution of phlD-containing dicotyledonous crop-associated biocontrol pseudomonads of worldwide origin. FEMS (Fed. Eur. Microbiol. Soc.) Microbiol. Ecol. 37:105-116.

Weller, D. M. 2007. Pseudomonas biocontrol agents of soilborne pathogens: Looking back over 30 years. Phytopathology 97:250-256.

Weller, D. M., Mavrodi, D. V., van Pelt, J. A., Pieterse, C. M. J., van Loon, L. C., and Bakker, P. A. H. M. 2012. Induced systemic resistance in Arabidopsis thaliana against Pseudomonas syringae pv. tomato by 2,4diacetylphloroglucinol-producing Pseudomonas fluorescens. Phytopathology 102:403-412.

\section{AUTHOR-RECOMMENDED INTERNET RESOURCE}

ImageJ software: imagej.nih.gov/ij 